\title{
Networks and Regional Economic Growth: A Spatial Analysis of Knowledge Ties
}

\author{
Robert Huggins \\ School of Planning and Geography, Cardiff University, Glamorgan Building, King \\ Edward VII Avenue, Cardiff, CF10 3WA, UK \\ E-mail: $\underline{\text { HugginsR@cardiff.ac.uk }}$ \\ Tel: +44 (0)2920876006
}

Piers Thompson

Nottingham Business School, Nottingham Trent University, $8^{\text {th }}$ Floor Newton Building, 50 Shakespeare Street, Nottingham, NG1 4FQ, UK

E-mail: piers.thompson@ntu.ac.uk

Tel: +44 (0) 1158482143

\begin{abstract}
In recent years, increased attention has been given to role of inter-organisational knowledge networks in promoting regional economic growth. Nevertheless, the empirical evidence base concerning the extent to which inter-organisational knowledge networks influence regional growth is at best patchy. This paper utilises a panel data regression approach to undertake an empirical analysis of economic growth across regions of the UK. Drawing on the concept of network capital, significant differences in the stocks of network capital and flows of knowledge within and across regions are found, which are significantly associated with regional rates of economic growth. The analysis finds that both inter and intra-regional networks shape regional growth processes, highlighting the role of both embedded localised linkages and the importance of accessing more geographically distant knowledge. The study adds weight to the suggestion that one of the most interesting implications of endogenous growth theory relates to the impact of the spatial organisation of regions on flows of knowledge. It is concluded that the adoption of a relational approach to understanding differing economic geographies indicates that network systems are a key component of the regional development mix.
\end{abstract}

Please cite this article as follows:

Huggins, R. and Thompson, P. (2017) 'Networks and Regional Economic Growth: A Spatial Analysis of Knowledge Ties', Environment and Planning A, doi: 10.1177/0308518X17692327

This is an Accepted Manuscript of an article published by Sage Journals in Environment and Planning A on $13^{\text {th }}$ February 2017, available online: http://dx.doi.org/10.1177/0308518X17692327 


\title{
Networks and Regional Economic Growth: A Spatial Analysis of Knowledge Ties
}

\begin{abstract}
In recent years, increased attention has been given to role of inter-organisational knowledge networks in promoting regional economic growth. Nevertheless, the empirical evidence base concerning the extent to which inter-organisational knowledge networks influence regional growth is at best patchy. This paper utilises a panel data regression approach to undertake an empirical analysis of economic growth across regions of the UK. Drawing on the concept of network capital, significant differences in the stocks of network capital and flows of knowledge within and across regions are found, which are significantly associated with regional rates of economic growth. The analysis finds that both inter and intra-regional networks shape regional growth processes, highlighting the role of both embedded localised linkages and the importance of accessing more geographically distant knowledge. The study adds weight to the suggestion that one of the most interesting implications of endogenous growth theory relates to the impact of the spatial organisation of regions on flows of knowledge. It is concluded that the adoption of a relational approach to understanding differing economic geographies indicates that network systems are a key component of the regional development mix.
\end{abstract}

\section{Introduction}

Economic growth rates are increasingly considered to be dependent on endogenous factors, with most treatments commonly assuming that economic growth is partly a function of either stocks of human capital (Lucas, 1988), or knowledge in the form of research and development (R\&D) (Romer, 1986). Romer (1986), for example, specifies a model of longrun growth in which knowledge is assumed to be an input into production that has increasing marginal productivity. A recent development to this approach is the increased attention that has been given to role of inter-organisational knowledge networks in promoting economic growth, especially the growth of regions. In particular, it has been suggested that regional economic growth is partly a function of the value created through inter-organisational flows of knowledge within and across regions (Huggins and Thompson, 2014; 2015). More generally, the role of inter-organisational networks as facilitators of knowledge flow has increasingly come to prominence across the economics, geography and management fields (Bergenholtz and Waldstrøm, 2011; Maggioni and Uberti, 2009; Zucker et al, 2007).

Inter-organisational networks consist of the interactions and relationships organisations (principally firms) utilise to access knowledge beyond their market relationships. In other words, these networks consist of the means by which knowledge flows across organisations beyond the direct purchasing of it. In general, inter-organizational networks are considered to be a crucial element underlying the economic growth and success 
of regions (Asheim et al, 2003; Bathelt et al, 2004; Rutten and Boekema, 2007). Furthermore, it has been proposed that investment in calculative networks by organizations to access knowledge is a form of capital, termed network capital (Huggins, 2010). Network capital reflects the accessible knowledge flows generated from the interactions and links formed between firms and other organisations. Given the growing importance of activities associated with open innovation, it has been suggested that network capital should be incorporated into regional growth models alongside the more traditional capital inputs (Huggins and Thompson, 2014). Network capital provides a useful means of accounting for the nature and value of the interactions and relationships required for knowledge to both 'spillover' and be captured (Fitjar and Huber, 2014; Huggins and Johnston, 2010; Kramer et al, 2011).

Huggins and Thompson (2014) outline a model of regional growth which is one of the first to incorporate network capital into the regional production function, but stop short of testing it. The aim of this paper, therefore, is to empirically examine the extent to which interorganisational networks facilitating the flow of knowledge - along with the acknowledged components of growth models, such as human capital, R\&D, physical capital and labour - are associated with regional growth processes. Furthermore, the paper seeks to recognise that access to, and the quality of, knowledge, varies according to the geographic distance between network actors. It study, therefore, seeks to answer the following research questions. First, to what extent is there evidence that network capital varies across regions? Second, is network capital positively associated with greater regional economic growth? Third, does the spatial nature of knowledge flows influence the relationship between regional economic growth and network capital?

The remainder of the paper is structured as follows. The literature associated with endogenous modes of regional economic growth and networks is explored in the next section. This includes an examination of the nature of firms' networks in terms of their spatial distribution, as well as the benefits or limitations of attempting to utilise more localised or distant knowledge. It further examines how the decision to draw on more geographically proximate or distant knowledge is driven by the characteristics of firms, in particular their stage of development. This helps provide an understanding of how network capital is likely to vary across regions. Section 3 outlines the methodological approach adopted for the analysis, detailing the estimation procedures used. Section 4 presents the results of the empirical analysis, which principally involves regression modelling techniques, with Section 5 discussing the implications for economic geography and regional development theory and policy. 


\section{Endogenous Regional Growth and Networks}

This section presents the key constructs and theoretical discourse associated with regional economic growth and the role of networks and knowledge flows as potentially determining factors. It firstly considers the work highlighting the role of intangible assets underpinning growth trajectories, before arguing that inter-organisational knowledge networks are themselves intangible assets, which can be portrayed as network capital. It then suggests that the spatial aspect of networks is linked to the value of networks for firms, as well as the regions in which they geographically situated. Finally, it is argued that the nature of the networks, and thus the value extracted, is related to the characteristics of the firms, especially lifecycle factors and the age of firms.

\subsection{Regional Growth and Network Capital}

At the regional level, it is recognised that there is a need to better understand the mechanisms underlying regional growth patterns (Andersson and Karlsson, 2007; Capello and Nijkamp, 2009; Stimson et al, 2011). Although there is a generally accepted view that networks provide the means for knowledge flow, there have been few attempts to incorporate the role of such networks within regional growth models. This is surprising given that the network metaphor has become commonplace within the regional economic development literature, with research focusing on notions such as innovative milieu, regional innovation systems and clusters, which all suggest the relevance of networks to regional economic performance (Allen, 2010; Cooke et al, 2011; Thrift and Olds, 1996; Yeung, 1994).

Fitjar and Rodríguez-Pose (2015) consider the impact of collaboration on innovation using data for Norway's largest five city regions. They find that the institutions present play an important role in mediating the effectiveness of the collaboration-innovation relationship. As the external knowledge captured through collaboration is of most value for open innovation activities, returns are maximised when combined with existing regional knowledge (regional $R \& D$ investment) and where firms possess the absorptive capacity (human capital) to make use of this knowledge.

Building on this approach, the empirical analysis presented in the following sections of this paper is positioned within the 'capitalisation' of networks discourse, whereby networks are considered to potentially offer benefits to network actors in terms of the resources they are able to access (Borgatti and Halgin, 2011; Capaldo, 2007; Glückler, 2013). It draws on the notion of network capital defined as the value actors gain from the knowledge 
they are able to access from their networks as a means of innovating and enhancing economic returns (Huggins and Thompson, 2014). In particular, network capital refers to the deliberate and calculative investment in relations and interactions by organisations, especially firms, with other organisations (Huggins and Johnston, 2010; Kramer and Revilla Diez, 2012; Lawton Smith et al, 2012). Network capital, therefore, is a relational asset stemming from strategic inter-organizational networks designed specifically to facilitate knowledge flow, innovation and to accrue economic advantage for organisations (Huggins and Thompson, 2014).

This conceptualization of network capital has some commonality with Elliot and Urry's (2010) description of it as being a resource 'advantage' that binds global elites together, but also differs in an important manner. Much of what might be considered network capital in Elliot and Urry's (2010) definition could be considered by others as incorporating social capital, as it specifically relates to personal connections between individuals. The term network capital as analysed in this study relates to the calculative relations residing at the firm rather than the individual level (Huggins and Johnston, 2010).

Duranton (1999) identifies personal face-to-face interactions as a factor that helps to glue agglomerations together. This echoes the notion of 'intra-regional network capital' operationalised in this study, which may have an important role in more tacit knowledge exchange. However, the notion of 'inter-regional network capital' appeals more to Duranton's (1999) argument that advances in technology will reduce the role of spatial agglomeration and may eventually remove the need for geographical proximity.

As intangible capital structures, networks can be considered to exist as capital objects (Westlund, 1999), and in this sense the term 'network' covers a wide range of interactions. As noted by Contractor and Lorange (2002), they may be either horizontal or vertical in nature and involve, for example, customers, suppliers, members of professional networks, rival firms, private and public sector knowledge providers, and universities.

\subsection{Network Spatiality}

A key feature of the network discourse has long concerned the role of interactions and associations between spatially proximate and co-located external organisations, such as universities, R\&D labs, and firms, within the innovation process (Keeble et al, 1999; Laursen et al, 2012; Mattes, 2012). It is argued that spatial proximity allows for repeated and frequent face-to-face interactions that enable the transfer of tacit knowledge that cannot be easily codified (Asheim and Gertler, 2005). This suggests that local organisations may often be 
embedded in regional knowledge channels (Breschi and Lissoni, 2009; Breschi and Malerba, 2001; Krätke, 2010), with ready access to local public or private research institutes and universities being facilitated through local knowledge flow routes (Mueller, 2006). However, while organisations may benefit from local knowledge spillovers as an undirected and spontaneous 'buzz' (Storper and Venables, 2004), they may also need to consciously build non-local 'pipelines' to tap into knowledge from outside their region (Bathelt et al, 2004).

In order to obtain the most valuable knowledge it may be necessary to utilise networks at a greater geographical scale (Bathelt et al, 2004; Lorentzen, 2008; Wolfe and Gertler, 2004). As a result, there is an increasing emphasis on the importance of understanding networks and knowledge flows that are simultaneously intra and inter-regional (Agrawal et al, 2008; Bouba-Olga et al., 2012; D’Este et al., 2013). There is also a growing school of thought that non-proximate actors are often equally, if not better, able to transfer strategically relevant and valuable knowledge across spatial boundaries providing a high performing network structure is in place (Torre, 2008).

Accessibility to extra-regional knowledge is found to be theoretically and empirically associated with regional growth performance, with the 'amount of knowledge' available in a region reinforcing the effect of local innovative activities (Rodríguez-Pose and Crescenzi, 2008; Andersson and Karlsson, 2007). In particular, it has been found that inflows of knowledge have a positive impact on the growth of a region, with this effect having a larger magnitude if neighbouring regions also exhibit high growth rates (Badinger and Tondl, 2002). Firms that source knowledge from selected providers located outside the local milieu will do so by investing in the building of new channels of communication (Fitjar and Rodriguez-Pose, 2011; Fontes, 2005; Gertler and Levitte, 2005). The concept of 'temporary clusters', whereby strategic network building occurs through conferences, trade fairs, exhibitions and the like, highlights the importance of investing in these channels to access knowledge via global pipelines (Bathelt and Schuldt, 2010; Maskell et al, 2006; Rinallo and Golfetto, 2011; Schuldt and Bathelt, 2011).

As Boschma and Ter Wal (2007) assert, innovation is not a matter of being in the right place, but more about being a member of the right network, with too much reliance on local knowledge networks and sources being potentially harmful for innovation. While regional knowledge flows are characterised by a higher number of face-to-face contacts, in some cases knowledge exchanged through non-regional flows have been found to be more valuable (Weterings and Ponds, 2009). More generally, the constraining effect of distance on knowledge flow and transfer is considered by some to be gradually diminishing, and there is 
increasing evidence of the heightened role being played by international knowledge sourcing networks in many places across the globe (Athreye, 2004; Doloreux, 2004; Garnsey and Heffernan, 2005; Saxenian, 2005). However, Fitjar and Rodríguez-Pose (2015) also highlight the importance of regional institutions in successfully utilising knowledge depending on the geographical proximity of the source. For international knowledge, they find that regional absorptive capacity is a key factor in generating greater innovative performance, but for domestic inter-regional knowledge the degree of regional $R \& D$ investment - reflecting the quality of the regional knowledge available - plays an important role.

Potentially, there is some interdependency between local and global networks. In particular, successful connectivity in global spaces is often considered to be the outcome of an initial system of localised interaction, whereby it is the knowledge crossing hallways and streets that initially catalyses intellectual exchange and knowledge transfer across oceans and continents (Glaeser et al, 1992). Skills gained through local interactions in knowledge-rich environments may better prepare firms for obtaining knowledge from distant sources (Saxenian, 2005; Sturgeon, 2003; Ter Wal and Boschma, 2011). This phased transition is necessitated by the risk for firms of becoming rigid and outdated when local networks fail to keep abreast of knowledge emerging outside of their respective region (Bathelt et al, 2004; Ter Wal and Boschma, 2011). Not all firms may participate in the transition from local to global interactions. Whereas firms with less resources and lower absorptive capacity (Cohen and Levinthal, 1990) may tend to continue to mainly network locally, those with greater resources and higher absorptive capacity are likely to be more connected to global networks (Drejer and Lund Vinding, 2007; Huggins and Johnston, 2009). It is, therefore, unclear whether network capital associated with geographically more proximate or distant sources will have the strongest association with regional growth.

\subsection{Networks and Firm Vintage}

As touched on above, the quantity and nature of network capital present in a region will be determined to some extent by the characteristics of the firms present within the region. As firms evolve it can be anticipated that their networks will evolve from relatively pathdependent networks - which in the first instance may be highly reliant on the pre-existing networks of the entrepreneur(s) - to more intentionally managed networks based on reputation and access to relevant resources and partners (Hite and Hesterly, 2001). Evidence suggests that as firms become more established, and potentially less vulnerable, the apparent necessity for network formation may initially fall, although over time increased reputation 
and status may increase the opportunity to form valuable network ties, resulting in an upward trend in the long-term (Deeds and Hill, 1996; Eisenhardt and Schoonhoven, 1996; Stern et al, 2014). Research indicates that a U-shaped relationship exists between the frequency of knowledge networking activity and the age of firms (Huggins et al, 2015). These findings offer broad support for propositions suggesting that the knowledge networks of firms evolve as the needs, capabilities, and characteristics of firms change in line with their position at particular points in their lifecycle. In particular, during the emergence phase firms make significant investments in networks as a means of accessing the knowledge they require (Baum et al, 2000; Athreye, 2004; Garnsey and Heffernan, 2005). Also, the location of knowledge sources, as well as the forms of knowledge and types of knowledge sources, tends to vary across firm age groups (Huggins et al, 2015). Overall, therefore, it is expected that networks will differ in scale and nature across regions, resulting in variations in the stocks of network capital.

In summary, the above critique seeks to argue that the growth of regions will partly result from the stocks of network capital held by firms located in respective regions. High growth regions are likely to be those with a dense cadre of firms fostering heightened endowments of global and inter-regional network capital in tandem with strong existing stocks of local intra-regional network capital. The following sections seek to determine the extent to which empirical analysis can be said to add support to these propositions.

\section{Data and Methods}

This section outlines the procedures used to estimate the stocks of network capital across UK NUTS2 regions as a means of testing for any relationships with regional output growth. As a starting point we draw on the findings of Huggins et al (2015) who find a relationship between firm age and knowledge networks based on a survey of firms in the UK. Huggins et al. (2015) use a UK wide survey of firms to determine the extent to which firms seek knowledge from a range of sources including suppliers, customers, rival firms, consultants, commercial labs, universities, government research institutes, conferences, rated from 0 (never) to 10 (very often). This is used to capture the extent to which firms are attempting to create and utilize network ties. For each source they identify whether knowledge was sought from within the region in which the firm is located (intra-regional), elsewhere in the UK (inter-regional national), or other countries (inter-regional international). The figures used here relate to the average intensity of use of regional, national and international sources 
regardless of the type of source within each. This contrasts with Fitjar and Rodríguez-Pose's (2015) approach where the variety of different types of knowledge sources is investigated in terms of its influence on the likelihood of innovating.

Here we concentrate on the extent to which network ties are used, rather than whether they just exist. The data are used to produce regional estimates of network capital by examining the use and formation of these network ties for firms of different ages. Based on the assumption that the relationship between firm age and network activity is consistent across firms in the UK, the Huggins et al. (2015) data allows the frequency of the knowledge networking of firms in each region to be estimated at the three spatial levels. Their findings were that whilst firms initially (up to five years from formation) invest more heavily in the formation of network ties, they appear to enter a growth (in income) phase (6 to 10 years after formation) where less investment is put into network ties. More mature and established firms (more than 10 years after formation) then return to a greater concentration on generating new network capital. From the spatial perspective, firms tend to network most frequently with knowledge sources located in UK regions outside of their own, followed by intra-regional sources, and less so international knowledge sources. Network tie scores are calculated for all firms in the region based on their age and the average networking frequency for firms of these ages.

Whilst the relationship between firm age and knowledge network patterns allows a network tie score to be generated at the three spatial levels for all firms in each region, this does not take account of the quality or value of the knowledge sourced. Therefore, in order to produce a more refined network capital score, account is also taken of the knowledgeintensity of the sector in which each firm operates, as means of partly accounting for institutional attributes (Fitjar and Rodríguez-Pose, 2015). This means that for each firm in the region the final network capital scores consist of networking by age scores being multiplied by the ratio of the industry $R \& D$ intensity to the average UK firm $R \& D$ intensity (captured by $R \& D$ expenditure as a percentage of value added). The regional firm age and industry data are drawn from the Office for National Statistics (ONS) UK Business: Activity, Size and Location, and Business Demography datasets. The R\&D intensity figures are drawn from the OECD Business enterprise R\&D expenditure by industry data for the UK. Network capital stock per region is calculated as the aggregate of the individual firm network capital scores determined by their age and industry as shown below: 


$$
W_{r, t}=\sum_{i=1}^{I} w_{i j, t} r d_{j}
$$

Where $w_{i j r, t}$ is the network tie score for firm $i$ from industry $j$ in region $r$ based on the age band that the firm belongs to in period $t$. This is multiplied by $r d_{j}$, which represents the R\&D intensity of industry $j$. The sum of these individual firm values provides the overall network capital score for region $r$ in period $t\left(W_{r, t}\right)$.

The network capital scores are created at each of the three spatial levels and as a total network capital value based on the sum of the three spatial level values. The average network capital creation and maintenance values for the three age groups of firms from Huggins et al. (2015) drive the differences between these measures. These estimates of regional network capital stocks can then be examined for their influence on GVA growth as suggested by Huggins and Thompson's (2014) model. Consistent regional data is available for the period 2005-2013 for the 37 NUTS2 regions in the UK. Initial investigation of this relationship considers growth at the NUTS2 regional level as captured by GVA. In order to examine the impact on development more directly, the growth of GVA per capita can be used to account for population changes.

In order to robustly estimate the impact of network capital on regional economic growth, a regression analysis is employed that also seeks to control for the role of other inputs into the growth process through a panel data approach. As the data is likely to exhibit non-stationary traits, the first differences of this data is likely to be required providing a total of 296 observations. As growth rates are likely to be the most valuable form these first differences are taken from natural log of the variables (equation 2).

$$
\begin{aligned}
\Delta \ln G V A_{r, t}= & \alpha_{0}+\alpha_{1} \Delta \ln K_{r, t}+\alpha_{2} \Delta \ln R D_{r, t}+\alpha_{3} \Delta \ln W_{r, t} \\
& +\alpha_{4} \Delta \ln h_{r, t}+\alpha_{5} \Delta \ln L_{r, t}+\alpha_{6} S_{r} \Delta \ln G V A_{q, t}+\varepsilon_{r, t}
\end{aligned}
$$

Gross Value Added $\left(G V A_{r, t}\right)$ figures are taken from the ONS estimates. Physical capital stocks $\left(K_{r, t}\right)$ are not available, instead gross fixed capital formation figures are used from Cambridge Econometrics's European Regional Database. As well as the network capital $\left(W_{r, t}\right)$ estimates outlined above, knowledge inputs are accounted for in the form of Research and Development investment $\left(R D_{r, t}\right)$ (Eurostat).

Although the growth of resources such as labour, human capital and physical capital inputs capture resources that are available for the regional economy, they do not identify the extent to which these resources are being utilised to boost innovative activities, and through 
this the long-term competitiveness of a region. In this case, expenditure on R\&D provides a proxy measure of the extent to which resources are being directed towards these activities. Total R\&D expenditure is used, as private research is seen as complementing pure public research that overcomes market failures (Guellec and van Pottelsberghe de la Potterie, 2004). Employment within R\&D positions was also considered as an option; however, there was considerable missing data at the NUTS2 level of analysis

Human capital $\left(h_{r, t}\right)$ is measured as the number of individuals with NVQ level 4 qualifications or higher (corresponding to first university degrees) (Annual Population Survey). This variable controls for the widely recognised relationship between human capital that captures not just the quantity but also the quality of the resource available (Faggian and McCann, 2009). University education is used as studies recognise that with the growing importance of the knowledge economy, it is education of this level that is often the most valuable (Brown et al, 2008; Faggian and McCann, 2006). However, to recognise the importance of labour in general - both skilled and unskilled - the working age population 1664 years (NOMIS mid-year population estimates) is also included in the regressions. As well as providing more direct inputs into production, growing populations may also provide a larger market for the outputs of entrepreneurial endeavours (Lee et al., 2004).

An advantage of using NUTS2 data over more aggregated data is that it enables greater heterogeneity within larger NUTS1 regions to be captured. NUTS1 (e.g. London, Yorkshire, Scotland and Wales) regions may be core or peripheral, but may also themselves contain core and peripheral areas. At a smaller level of aggregation it is likely that there will be spillovers and interactions between NUTS2 regions (Badinger and Tondl, 2002). To capture this we include a spatial lag term $S_{r}$, the spatial weights that represent whether other regions $(q \neq r)$ share a border with region $r$. The spatial weights are such that when applied the spatial term captures the average growth rate of the Gross Value Added variable in the surrounding NUTS2 regions.

\section{Results}

Figure 1 presents the relationship between average total network capital per firm and GVA per capita in 2013 by NUTS2 region (excluding the outlier of Inner London due to the anomalistic nature of its GVA per capita). A positive link is found with a line of best fit explaining 42.2 per cent of the variance, suggesting that firms in economically leading regions generally hold higher stocks of network capital. In answer to the first research question, it is clear that there is considerable variation in the levels of network capital held by 
firms across regions. Furthermore, not all regions have seen increases in the level of total network capital present over the period 2005 to 2013. The weakening of the global economy has been accompanied by a reduction in average network capital for 12 out of 37 of the regions. Rural areas such as Cumbria (-27.0 per cent) and Devon (-9.8 per cent) are the regions displaying the largest declines in total network capital per firm.

\section{PLEASE INSERT FIGURE 1 ABOUT HERE}

In order to determine any relationships between network capital and regional economic growth account needs to be taken of changes in other factors that may have an impact on NUTS2 regional growth, necessitating the use of a multivariate analysis. In preparation for the panel data analysis, Table 1 presents the correlation matrix for the network capital measures, GVA, and other sources of labour and capital traditionally associated with regional growth using individual years of data. In general, it can be seen that there does appear to be a positive relationship between all sources of network capital and gross value added. Table 1 also indicates the strong but imperfect correlation between network capital measures disaggregated by source.

\section{PLEASE INSERT TABLE 1 ABOUT HERE}

Table 2 presents the results of estimating the relationships set out in equation 2. The regressions allow for random effects to account for unobserved regional and period characteristics. The regressions explain around 42.5 per cent of the variance in GVA growth. The regression results suggest that network capital investments may positively link to regional output growth, with total network capital significantly associated with output growth at the 5 per cent level. In relation to the second research question, the predictions of studies such as Allen (2010) and Huggins and Thompson (2015) are supported, with it indicated that relatively high growth regions possess firms with relatively high stocks of network capital, which allows them to access the most economically beneficial knowledge. Firms in lower growth regions are more likely to have a relative dearth of network capital, resulting in knowledge access capabilities being restricted to the sourcing of relatively inferior knowledge that may hinder their ability to learn (Rutten and Boekema, 2007).

As well as the overall relationship between network capital and growth, the third research question is aimed at establishing the importance of the spatial nature of this network 
capital. When breaking down network capital by the geographical location of the ties, positive coefficients are estimated for all three forms of network capital. Partly confirming the growing importance of global and non-local knowledge networks (Huggins and Izushi, 2007; Rodríguez-Pose and Crescenzi, 2008), inter-regional international network capital is significantly related to GVA growth at the 10 per cent level. However, the strongest relationships are between GVA growth and inter-regional national network capital and intraregional network capital. With regard to the latter, this may mean that easier access to geographically proximate intra-regional sources of knowledge ensure that these network ties remain important with regard to creating a local buzz (Bathelt et al., 2004), even though there may be a degree of informational redundancy (Maurer and Ebers, 2006; Ter Wal and Boschma, 2011).

The relatively strong relationship between both intra-regional and national interregional network capital and GVA growth may be reflective of the fact that the majority of firms in many regions may struggle to absorb knowledge from more distant global sources (Drejer and Lund Vinding, 2007; van Geenhuzen, 2008). This is consistent with those studies that have noted the important role played by institutions, such as universities, as knowledge aerials, effectively drawing in national and international knowledge and converting it for use by local firms, in particular SMEs (Brandt et al, 2009; Fritsch and Schwirten, 1999; Lorenzen, 2007). The development of entrepreneurship from these regional knowledge aerials may be key factor in facilitating regional growth in the long run, as firms develop to the stage where they can also access global knowledge networks (Audretsch and Keilbach, 2005).

It is important to recognise that there are considerable growth spillovers between the NUTS2 regions as captured by the spatial lag term, which is significant at the 1 per cent level. Although knowledge flow within regions is found to be important, it is possible that NUTS2 regions adjacent to regions with greater inter-regional international network capital growth are also benefitting from indirect interactions. Whilst such benefits may not require collaboration and networking with firms in neighbouring regions, the positive coefficient for inter-regional national network capital indicates that such interaction may well take place.

Studies have increasingly noted the importance of global knowledge pipelines, and the results presented here provide evidence to support this (McEvily and Zaheer, 1999; Torre, 2008). Firms with more inter-regional connectivity may act as bridges between particular spatial clusters, and be well-positioned to manage and influence knowledge flows, presumably to maintain high rates of innovation. Furthermore, firms with a high propensity to 
engage in interactions with actors in other regions may hold central positions within knowledge networks, suggesting the importance of these firms as boundary spanning and bridging agents and as centrally positioned nodes within a wider spatially configured network architecture (Fleming and Waguespack; 2007; Cassi and Plunket, 2015). Therefore, those regions with open and porous regional innovation systems are more likely to have higher rates of economic growth. This adds weight to the argument that spatially unbounded knowledge networks and innovation systems are an increasingly important element of routes for achieving regional economic growth (Torre, 2008; Huggins and Thompson, 2014).

Clearly, knowledge does not flow rapidly and costlessly around the globe (Grossman and Helpman, 1994), and, as Malecki (2010) argues, the globalisation of knowledge may result in additional costs as firms communicate across national, cultural and linguistic boundaries. Therefore, the costs of establishing and sustaining inter-organizational knowledge flows are likely to rise with geographical distance (Weterings and Ponds, 2009). The evidence presented here suggests that regions with firms possessing a proclivity to invest in more spatially distant forms of network capital are likely to achieve higher rates of growth. As noted above, however, it may be that developing inter-regional national network capital is the most efficient manner of achieving this for many regions. Firms following this route can then benefit from trading and collaborative relationships with firms in neighbouring regions, especially those with greater inter-regional international network capital.

Understandably, physical capital from gross fixed capital formation and increases in labour inputs are found to significantly increase GVA growth. Surprisingly, R\&D employment and broader human capital are not significantly associated with GVA growth. This may reflect the increasing importance of global knowledge flows (Teixeira et al, 2006; Torre, 2008), and whilst one would expect human capital to contribute to growth by increasing the absorptive capacity of the region to make the best use of knowledge flows (Caragliu and Nijkamp, 2012), the network capital measures used here already account for this through the incorporation of the R\&D intensity of individual firms (Cohen and Levinthal, 1990).

\section{PLEASE INSERT TABLE 2 ABOUT HERE}

\section{Discussion and Conclusion}

This paper has built upon existing studies suggesting that network capital may be an important input into regional economic growth. Using panel data regression approaches, the 
results of the study show that the network capital stock of a region plays a role in determining its economic growth. Intra-regional network capital is found to have a strong and significant relationship with growth, highlighting the role of embedded localised linkages. Similarly, the positive and significant relationship between growth and inter-regional network capital indicates the importance of accessing more geographically distant knowledge. These findings add weight to the suggestion that one of the most interesting implications of endogenous growth theory relates to the impact of the spatial organisation of regions on flows of knowledge (Roberts and Setterfield, 2010). In particular, the findings confirm that differences in regional growth can be partly explained by differences in the conditions for creating, accumulating and - crucially - transmitting knowledge. In part, the results indicate that increasing regional economic returns are realised through both the geographic and organizational processes resulting from both the localisation and more spatial diffusion of knowledge (Pred and Hagerstrand 1967; Storper, 2009).

From a theoretical perspective, the paper has attempted to highlight the value of the network metaphor in explaining patterns of uneven regional development. The determinants of regional development are clearly multi-dimensional, but the adoption of a relational approach to understanding differing economic geographies, especially through the study of the spatiality of knowledge flows (Bathelt and Glückler, 2005), indicates that network systems are a key component of the regional development mix. In particular, the notion of network capital is one means of seeking to conceptualise, analyse and measure the relationship between network systems and regional development. Therefore, it can be suggested that theoretical, empirical and policy-driven research and practice relating to networks and regional development should take a more systemic approach to incorporating the structure (the position of regions and their firms within knowledge networks), strength (the nature and frequency of interactions) and spatiality (geographic reach) of ties.

Whilst the network capital concept seeks to encapsulate these variables, like other approaches in the field of relational economic geography it has been argued that its explanatory power is partly limited due a flat ontology that, amongst other matters, takes little account of the institutions and social structures underpinning the emergence and evolution of networks (Jonas, 2006; Sunley, 2008). As a means of bridging this theoretical gap between relational 'capital' and 'institutional' explanations of uneven regional development, efforts need to be made to reconcile capital accumulation models of regional development with emerging institutional theories (Huggins, 2016). 
Given that the network metaphor can be conceptualised and analysed from both a capitalisation (ties and pipelines) and an institutional (governance and coordination) perspective (Sunley, 2008; Glückler, 2013), it remains a potentially fruitful means of understanding the growth and development systems of regions from a more theoretically integrated standpoint. Indeed, knowledge networks and the 'easy flow of ideas' have for a number of years been argued to be one of the key explanatory factors underlying the reasons why regions often grow and flourish (Glaeser et al., 1992; Gordon, 2013). An institutional perspective on these networks and flows would suggest that firms are incentivised to engage in networked activity through the availability of formal associational institutions such as chambers of commerce, business and trade associations, as well more informal institutions in the form of the geographic clustering of firms within which networked cooperation and collaboration is fostered through embedded norms and customs (Cooke and Morgan, 1998; Farole et al., 2011).

Even in the globalised world, the enduring importance of local network capital has important implications for policy. It seems possible that not all regions possess a large number concentration of firms capable of tapping into global pipelines (van Geenhuzen, 2008). In such regions, it may be more productive to support the development of intraregional network capital to help circulate knowledge within the region. Within the UK policy context, the demise of the Regional Development Agencies (RDAs) means that new localised policy support configurations such as Local Enterprise Partnerships (LEPs) and City Regions would appear to be best placed to support such activities (Ward, 2015). Central government funding, however, would be required to develop these institutions and allow them to fulfil this and other economic development roles (Pugalis and Bentley, 2013).

Importantly, LEPs and City Regions could also have a significant role in helping the development of inter-regional network capital (Bathelt et al., 2004; Maurer and Ebers, 2006; Ter Wal and Boschma, 2011). This could be achieved by direct collaboration between LEPs and City Regions, such as through the Core Cities initiative (Core Cities, 2016), where leading firms, research institutions, universities and policymakers in different regions look to further develop their inter-regional network capital. With a greater potential to form less geographically proximate network capital, these organisations could take on the 'knowledge aerial' role identified by Fritsch and Schwirten (1999). Past experience indicates that this may not always occur naturally, and regional institutions have a key role to play in both bringing together actors with the ability to generate inter-regional network capital and also to ensure the dissemination of knowledge within the region. 
Financial incentives to support inter- and intra-regional collaboration between groups such as SMEs with large firms and universities may be highly beneficial. However, it is also likely that advice, support and experienced intermediaries will be required to govern these relationships, as overcoming cognitive distance can be just as difficult as negotiating the barriers associated with spatial distance (Deschamps et al., 2013; D’Este et al., 2013). Currently such an approach looks far from achievable, in part because of the unclear responsibilities and limited coordination between the different layers of local, regional and central government and institutions in the UK (Pugalis et al., 2012; Rees and Lord, 2013), as well as variations across LEP areas in these arrangements (O'Brien and Pike, 2015). Although a one-size-fits all approach is clearly not suitable, in order to help create the different forms of interaction, collaboration and cooperation associated with network capital some clarity and consistency needs to be provided by central government (MacKinnon et al., 2015).

There are possibilities to extend the analysis undertaken here in a number of directions. The implications of the findings of this study and others show the importance of considering network capital at different spatial levels. As indicated, it seems that interregional international network capital may be less effective for many firms because of weaknesses in acquiring and absorbing knowledge from global networks (Drejer and Lund Vinding, 2007). This makes those firms and institutions that contribute to inter-regional international network capital highly valuable elements of both regional and global knowledge networks. Therefore, new studies concerning network robustness would be of considerable value in capturing the reliance of more peripheral regions on a small number of such actors. This would provide insights into where policy might be best directed in terms of securing inter-regional links and ensuring the effective transmission of knowledge from these links through intra-regional network capital.

Whilst attention in this paper has focused on the spatial aspects of network capital, there is scope to further consider the dynamism and flexibility of network ties. Similarly, more work should be undertaken on understanding the role of network tie variety (Fitjar and Rodríguez-Pose, 2015). Furthermore, this study does not explicitly incorporate the development of 'entrepreneurship capital' as outlined by the knowledge spillover theory of entrepreneurship (Audretsch and Lehmann, 2005). Future studies may look to include this mechanism into their analysis, which could be achieved through new business starts being incorporated as an endogenous part of regional growth systems. From this perspective, the role of institutions in promoting such activities is likely to be important (Fitjar and 
Rodríguez-Pose, 2015). Finally, it is clear that this study incorporates a relatively short time period covering a relatively small number of regional observations, and future studies should seek to extend both the longitudinal and spatial coverage of their analyses, as well as considering more sophisticated means for capturing network capital indicators.

\section{References}

Agrawal A, Kapur D, McHale J, 2008, "How do spatial and social proximity influence knowledge flows? Evidence from patent data” Journal of Urban Economics 64(2) 258-269

Allen J, 2010, 'Powerful city networks: more than connections, less than domination and control” Urban Studies 47(13) 2895-2911

Andersson M, Karlsson C, 2007, "Knowledge in regional economic growth: the role of knowledge accessibility" Industry and Innovation 14(2) 129-149

Asheim B T, Gertler M S, 2005, "The geography of innovation: regional innovation systems", in The Oxford Handbook of Innovation Eds J Fagerberg, D Mowery, R R Nelson (Oxford University Press, Oxford) pp 291-317

Asheim B, Isaksen A, Nauwelaers C, Tödtling F, (eds.) 2003 Regional Innovation Policy for Small-Medium Enterprises (Edward Elgar, London)

Athreye S, 2004, "Agglomeration and growth: A study of the Cambridge hi-tech cluster", Building high-tech clusters Silicon Valley and beyond Eds T Bresnahan, A Gambardella (Cambridge University Press, Cambridge \& New York) pp 121-159

Audretsch D B, Keilbach M, 2005, "Entrepreneurship capital and regional growth” Annuals of Regional Science 39(3) 457-469

Audretsch D B, Lehmann E E, 2005, "Does the Knowledge Spillover Theory of Entrepreneurship hold for regions?” Research Policy 34 1191-1202

Badinger H, Tondl G, 2002, "Trade, human capital and innovation: the engines of European regional growth in the 1990s”, In European Regional Growth Eds B Fingleton (Springer, Heidelberg) pp 215-240

Bathelt H, Malmberg A, Maskell P, 2004, "Clusters and knowledge: local buzz, global pipelines and the process of knowledge creation" Progress in Human Geography 28(1) 31-56

Bathelt H, Glückler J, 2005, "Resources in economic geography: from substantive concepts towards a relational perspective” Environment and Planning A 37(9), 1545-1563

Bathelt H, Schuldt N, 2010, "International trade fairs and global buzz, Part I: Ecology of global buzz” European Planning Studies 18(12) 1957-1974

Baum J, Calabrese T, Silverman B S, 2000, “Don’t go it alone: alliance network composition and startups' performance in Canadian biotechnology” Strategic Management Journal 21(3) 267-294

Bergenholtz C, Waldstrøm C, 2011, “Inter-organizational network studies: A literature review” Industry and Innovation 18(6) 539-562

Borgatti S P, Halgin D S, 2011, “On network theory” Organization Science 22(5) 1168-1181

Boschma R, Ter Wal A, 2007, "Knowledge networks and innovative performance in an industrial district: The Case of a footwear district in the South of Italy" Industry and Innovation 14 177-199

Bouba-Olga O, Ferru M, Pépin D, 2012, "Exploring spatial features of science-industry partnerships: a study on French data” Papers in Regional Science 91(2) 355-375 
Brandt A, Hahn C, Krätke S, Kiese M, 2009, "Metropolitan regions in the knowledge economy: network analysis as a strategic information tool” Tijdschift voor Economische en Sociale Geografie 100(2) 236-249

Breschi S, Lissoni F, 2009, "Mobility of skilled workers and co-invention networks: an anatomy of localized knowledge flows” Journal of Economic Geography 9(4) 439-468 doi: 10.1093/jeg/lbp008

Breschi S, Malerba F, 2001, “The geography of innovation and economic clustering: some introductory notes” Industrial and Corporate Change 10 817-834

Brown P, Lauder H, Ashton D, 2008, "Education, globalisation and the future of the knowledge economy” European Education Research Journal 7(2) 131-156

Capaldo A, 2007, "Network structure and innovation: the leveraging of a dual network as a distinctive relational capability" Strategic Management Journal 28(6) 585-608

Capello R, Nijkamp P, (eds) 2009 Handbook of Regional Growth and Development Theories (Edward Elgar, Cheltenham)

Caragliu A, Nijkamp P, 2012, "The impact of regional absorptive capacity on spatial knowledge spillovers: the Cohen and Levinthal model revisited" Applied Economics 44(11) 1363-1374.

Cassi, L., Plunket, A. 2015, "Research collaboration in co-inventor networks: combining closure, bridging and proximities”. Regional Studies, 49(6): 936-954.

Cohen W M, Levinthal D A, 1990, "Absorptive capacity: a new perspective on learning and innovation” Administrative Science Quarterly 35(1) 128-152

Contractor F, Lorange P, 2002, "The growth of alliances in the knowledge-based economy" International Business Review 11(4) 485-205

Cooke P., Morgan, K. 1998, The associational economy: firms, regions, and innovation. Oxford: Oxford University Press.

Cooke P, Asheim B, Boschma R, Martin R, Schwartz D, Tödtling F, (eds) 2011 Handbook of Regional Innovation and Growth (Edward Elgar, Cheltenham)

Core Cities, 2016, Core Cities: Annual Report 2016, (Core Cities, Manchester)

Deeds D L, Hill C W L, 1996, "Strategic alliances and the rate of new product development: an empirical study of entrepreneurial biotechnology firms” Journal of Business Venturing 11(1) 41-51

Deschamps I, Macedo M G, Eve-Levesque C, 2013, "University-SME collaboration and open innovation: intellectual-property management tools and the roles of intermediaries” Technology Innovation Management Review 2013 33-41

D’Este P, Guy F, Iammarino S, 2013, "Shaping the formation of university-industry research collaborations: what type of proximity does really matter?” Journal of Economic Geography 13(4) 537-558

Doloreux D, 2004, "Regional innovation systems in Canada: a comparative study” Regional Studies 38 479-492

Duranton G, 1999, "Distance, land, and proximity: economic analysis and the evolution of cities” Environment and Planning A 31 2169-2188

Drejer I, Lund Vinding A, 2007, "Searching near and far: determinants of innovative firms' propensity to collaborate across geographical distance” Industry and Innovation 14 259-275

Eisenhardt K M, Schoonhoven C B, 1996, "Resource-based view of strategic alliance formation: strategic and social effects in entrepreneurial firms” Organization Science 7(2) $136-150$

Elliott A, Urry J, 2010, Mobile Lives (Routledge, Abingdon)

Faggian A, McCann P, 2006, "Human capital flows and regional knowledge assets: a simultaneous equation approach” Oxford Economic Papers 58(3) 475-500 
Faggian A, McCann P, 2009, "Human capital and regional development”, in Handbook of Regional Growth and Development Theories Eds R Capello and P Nijkamp (Edward Elgar, Cheltenham) pp 133-151

Farole T., Rodríguez-Pose A., Storper, M. 2011. "Human geography and the institutions that underlie economic growth” Progress in Human Geography, 35(1): 58-80.

Fitjar R D, Huber F, 2014, "Global pipelines for innovation: insights from the case of Norway” Journal of Economic Geography, 15(3): 561-583.

Fitjar R D, Rodríguez-Pose A, 2015, "Networking context and firm-level innovation: cooperation through the regional filter in Norway" Geoforum, 63(1) 25-35

Fleming L, Waguespack D M, 2007, "Brokerage, boundary spanning, and leadership in open innovation communities” Organization Science 18(2) 165-180.

Fontes M, 2005, "Distant networking: the knowledge acquisition strategies of 'out-cluster' biotechnology firms” European Planning Studies 13(6) 899-920

Fritsch M, Schwirten C, 1999, "Enterprise-university cooperation and the role of public research institution in regional innovation systems” Industry and Innovation 6(1) 6983

Garnsey E, Heffernan P, 2005, "High-technology clustering through spin-out and attraction: the Cambridge case” Regional Studies 39 1127-1144

Gertler M, Levitte Y, 2005, "Local nodes in global networks: The geography of knowledge flows in biotechnology innovation" Industry and Innovation 13 487-507

Glaeser E L, Kallal H D, Scheinkman J A, Shleifer A, 1992, "Growth in cities” Journal of Political Economy 100(6) 1126-1152

Glückler J, 2013, "Knowledge, networks and space: connectivity and the problem of noninteractive learning” Regional Studies 47(6) 880-894

Gordon, P., 2013, “Thinking about economic growth: cities, networks, creativity and supply chains for ideas” Annals of Regional Science, 50, 667-684

Grossman G M, Helpman E, 1994, “Endogenous innovation in the theory of growth” Journal of Economic Perspectives 8 23-44

Guellec D, van Pottelsbergje de la Potterie B, 2004, "From R\&D to productivity growth: do the institutional settings and the source of funds matter?" Oxford Bulletin of Economics and Statistics 66(3) 353-378

Hite J, Hesterly W S, 2001, "The evolution of firm networks: from emergence to early growth of the firm” Strategic Management Journal 22(3) 275-286

Huggins R, 2010, "Forms of network resource: knowledge access and the role of interfirm networks” International Journal of Management Reviews 12(3) 335-352

Huggins R, 2016, “Capital, institutions and urban growth systems” Cambridge Journal of Regions, Economy and Society 9(2) 443-463

Huggins R, Izushi H, 2007 Competing for Knowledge: Creating, Connecting and Growing (Routledge, London)

Huggins R, Johnston A, 2009, "Knowledge networks in an uncompetitive region: SME innovation and growth" Growth and Change 40(2) 227-259.

Huggins R, Johnston A, 2010, "Knowledge flow and inter-firm networks: the influence of network resources, spatial proximity, and firm size” Entrepreneurship and Regional Development 22(5) 457-484

Huggins R, Thompson P, 2014, “A network-based view of regional growth” Journal of Economic Geography 14(3) 511-545

Huggins R, Thompson P, 2015, "Entrepreneurship, innovation and regional growth: a network theory” Small Business Economics 41(5) 103-128 
Huggins R, Izushi H, Prokop D, Thompson P, 2015, "Network evolution and the spatiotemporal dynamics of knowledge sourcing” Entrepreneurship and Regional Development 27(7-8) 474-499

Jonas A E G, 2006, "Pro Scale: Further Reflections on the 'Scale Debate' in Human Geography” Transactions of the Institute of British Geographers 31(3), 399-406

Keeble D, Lawson C, Moore B, Wilkinson F, 1999, "Collective learning processes, networking and 'institutional thickness' in the Cambridge region” Regional Studies 33(4) 319-332

Kramer J-P, Revilla Diez J, 2012, "Catching the local buzz by embedding? Empirical insights on the regional embeddedness of multinational enterprises in Germany and the UK" Regional Studies 46(10) 1303-1317

Kramer J-P, Marinelli E, Iammarino S, Revilla Diez J, 2011, "Intangible assets as drivers of innovation: empirical evidence on multinational enterprises in German and UK regional systems of innovation” Technovation 31(9) 447-458

Krätke S, 2010, "Regional knowledge networks: A network analysis approach to the interlinking of knowledge resources” European Urban and Regional Studies 17(1) 83-97 doi: 10.1177/0969776409350794

Laursen K, Masciarelli F, Prencipe A, 2012, "Regions matter: how localized social capital affects innovation and external knowledge acquisition” Organizational Science 23(1) 177-193

Lawton Smith H, Romeo S, Virahsawmy M, 2012, "Business and professional networks: scope and outcomes in Oxfordshire” Environment and Planning A 44 1801-1818

Lee S Y, Florida R, Acs Z J, 2004, "Creativity and entrepreneurship: a regional analysis of new firm formation” Regional Studies 38(8) 879-891

Lorentzen A, 2008, "Knowledge networks in local and global space” Entrepreneurship and Regional Development 20 533-545

Lorenzen M, 2007, "Social capital and localised learning: proximity and place in technological and institutional dynamics” Urban Studies 44 799-817

Lucas R E, 1988, “On the mechanics of economic development” Journal of Monetary Economics 22(1) 3-42

MacKinnon D, Cumbers A, Featherstone D, 2015, "Local and regional economic development in Britain” in The British Growth Crisis: The Search for a New Model Eds. J Green, C Hay, P Taylor-Gooby (Palgrave Macmillan, Basingstoke) pp. 201220.

Maggioni M, Uberti T E, 2009, "Knowledge networks across Europe: which distance matters?” Annals of Regional Science 43(3) 691-720

Malecki E J, 2010, “Global knowledge and creativity: New challenges for firms and regions” Regional Studies 44 1033-1052

Maskell P, Bathelt H, Malmberg A, 2006, "Building global knowledge pipelines: The role of temporary clusters” European Planning Studies 14(8) 997-1013

Mattes J, 2012, "Dimensions of proximity and knowledge bases: Innovation between spatial and non-spatial factors” Regional Studies 46(8) 1085-1099

Maurer I, Ebers M, 2006, "Dynamics of social capital and their performance implications: lessons from biotechnology start-ups” Administrative Science Quarterly 51(2) 262292

McEvily B, Zaheer A, 1999, "Bridging ties: a source of firm heterogeneity in competitive capabilities” Strategic Management Journal 20(12) 1133-1156

Mueller P, 2006, "Entrepreneurship in the region: Breeding ground for nascent entrepreneurs?” Small Business Economics 27 41-58 
O’Brien P, Pike A, 2015, “City deals, decentralisation and the governance of local infrastructure funding and financing in the UK" National Institute Economic Review 233(1) R14-R26

Pred, A. R., Hagerstrand, T. 1967, Innovation Diffusion as a Spatial Process. Chicago, IL: University of Chicago Press.

Pugalis L, Bentley G, 2013, "Storming or performing? Local Enterprise Partnerships two years on” Local Economy 28(7/8) 863-874.

Pugalis L, Shutt J, Bentley G, 2012, "Local Enterprise Partnerships: living up to the hype” Critical Issues in Economic Development (Institute of Economic Development: Lower Whitley)

Rees J, Lord A, 2013, "Making space: putting politics back where it belongs in the construction of city regions in the North of England" Local Economy 28(7/8) 679-695

Rinallo D, Golfetto F, 2011, "Exploring the knowledge strategies of temporary cluster organizers: A longitudinal study of the EU fabric industry trade shows (1986-2006)” Economic Geography 87(4) 453-476

Roberts, M., Setterfield, M. 2010 "Endogenous regional growth: a critical survey". In M. Setterfield (ed.) Handbook of Alternative Theories of Economic Growth, pp. 431450. Cheltenham: Edward Elgar.

Rodríguez-Pose A, Crescenzi R, 2008, "Research and development, spillovers, innovation systems, and the genesis of regional growth in Europe” Regional Studies 42 51-67

Romer P M, 1986, "Increasing returns and long-run growth" Journal of Political Economy 94(5) 1002-1037

Rutten R, Boekema F, (eds.) 2007 The Learning Region: Foundations, State of the Art, Future (Edward Elgar, Cheltenham)

Saxenian A, 2005, "From brain drain to brain circulation: transnational communities and regional upgrading in India and China" Studies in Comparative International Development 40 35-61

Schuldt N, Bathelt H, 2011, "International trade fairs and global buzz. Part II: Practices of global buzz” European Planning Studies 19(1) 1-22

Sunley P, 2008, "Relational economic geography: A partial understanding or a new paradigm?” Economic Geography 84(1), 1-26

Stern I, Dukerich J M, Zajac E, 2014, "Unmixed signals: how reputation and status affect alliance formation” Strategic Management Journal 35(4) 512-531

Stimson R, Stough R R, Nijkamp P, (eds) 2011, "Endogenous regional development: perspectives, measurement and empirical investigation" (Edward Elgar, Cheltenham)

Storper, M. 2009 "Roepke lecture in economic geography: regional context and global trade”. Economic Geography, 85: 1-21.

Storper M and Venables AJ (2004) Buzz: Face-to-face contact and the urban economy. Journal of Economic Geography 4(4): 351-370.

Sturgeon T, 2003, "What really goes on in Silicon Valley? Spatial clustering and dispersal in modular production networks" Journal of Economic Geography 3(2) 199-225

Teixeira A, Santos P, Oliveira Brochado A, 2006, "Does proximity really matter in international R\&D cooperative projects?” Paper presented at the European Network on Industrial Policy (EUNIP) 9th International Conference, Limerick, Ireland, 20-22 June

Ter Wal A, Boschma R, 2011, "Co-evolution of firms, industries and networks in space" Regional Studies 45 919-933

Thift N, Olds K, 1996, "Refiguring the economic in economic geography" Progress in Human Geography 20(3) 311-337 
Torre A, 2008, “On the role played by temporary geographical proximity in knowledge transmission” Regional Studies 42(6) 869-889

van Geenhuizen M, 2008, "Knowledge networks of young innovators in the urban economy: biotechnology as a case study” Entrepreneurship \& Regional Development 20(2) 161-183

Ward M, 2015, “Local Enterprise Partnerships” House of Commons Library Standard Note, \#SN/EP/5651

Westlund H, 1999, “An interaction-cost perspective on networks and territory” Annals of Regional Science 33 93-121

Weterings A, Ponds R, 2009, "Do regional and non-regional knowledge flows differ? An empirical study on clustered firms in the Dutch life sciences and computing services industry” Industry and Innovation 16(1) 11-31

Wolfe D, Gertler M, 2004, "Clusters from the inside and out: local dynamics and global linkages” Urban Studies 41 1071-1093.

Yeung $\mathrm{H} \mathrm{W}$-c, 1994, "Critical reviews of geographical perspectives on business organizations and the organization of production: towards a network approach" Progress in Human Geography 18(4) 460-490

Zucker L G, Darby M R, Furner J, Liu R C, Hongyan M, 2007, “Minerva unbound: Knowledge stocks, knowledge flows and new knowledge production” Research Policy 36 850-863 
Figure 1: Network Capital per Firm and GVA per capita by NUTS2 Region, 2013

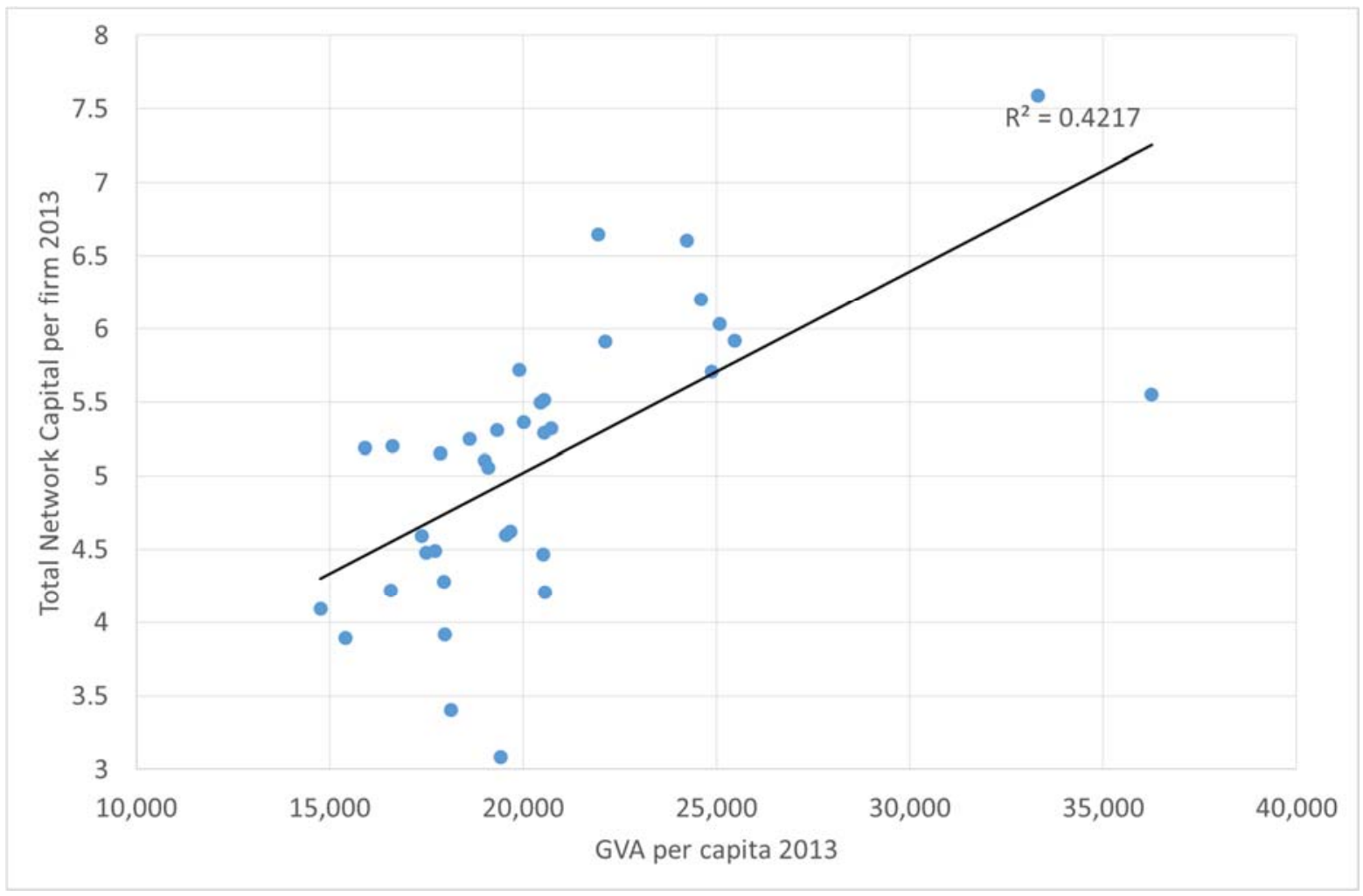




\begin{tabular}{|c|c|c|c|c|c|c|c|c|}
\hline & $\begin{array}{l}\text { 1. Gross } \\
\text { Value } \\
\text { Added }\end{array}$ & $\begin{array}{l}\text { 2. Total } \\
\text { Network } \\
\text { Capital }\end{array}$ & $\begin{array}{c}\text { 3. Inter- } \\
\text { Regional } \\
\text { International } \\
\text { Network } \\
\text { Capital } \\
\end{array}$ & $\begin{array}{c}\text { 4. Inter- } \\
\text { Regional } \\
\text { National } \\
\text { Network } \\
\text { Capital } \\
\end{array}$ & $\begin{array}{l}\text { 5. Intra- } \\
\text { Regional } \\
\text { Network } \\
\text { Capital } \\
\end{array}$ & $\begin{array}{c}6 . \\
\text { Physical } \\
\text { Capital }\end{array}$ & $\begin{array}{c}\text { 7. R\&D } \\
\text { Expenditure }\end{array}$ & $\begin{array}{c}8 . \\
\text { Human } \\
\text { Capital }\end{array}$ \\
\hline $\begin{array}{l}\text { 2. Total Network } \\
\text { Capital }\end{array}$ & $\begin{array}{l}0.2688^{* * *} \\
(0.000)\end{array}$ & & & & & & & \\
\hline $\begin{array}{l}\text { 3. Inter-Regional } \\
\text { International Network } \\
\text { Capital }\end{array}$ & $\begin{array}{l}0.2631^{* * *} \\
(0.000)\end{array}$ & $\begin{array}{c}0.997^{* * *} \\
(0.000)\end{array}$ & & & & & & \\
\hline $\begin{array}{l}\text { 4. Inter-Regional } \\
\text { National Network } \\
\text { Capital }\end{array}$ & $\begin{array}{l}0.2684^{* * *} \\
(0.000)\end{array}$ & $\begin{array}{c}1 * * * \\
(0.000)\end{array}$ & $\begin{array}{l}0.9972 * * * \\
(0.000)\end{array}$ & & & & & \\
\hline $\begin{array}{l}\text { 5. Intra-Regional } \\
\text { Network Capital }\end{array}$ & $\begin{array}{l}0.2683^{* * *} \\
(0.000)\end{array}$ & $\begin{array}{l}0.9996^{* * *} \\
(0.000)\end{array}$ & $\begin{array}{l}0.9957 * * * \\
(0.000)\end{array}$ & $\begin{array}{l}0.9994 * * * \\
(0.000)\end{array}$ & & & & \\
\hline $\begin{array}{l}\text { 6. Physical Capital } \\
\text { (Business Investment) }\end{array}$ & $\begin{array}{l}0.3894 * * * \\
(0.000)\end{array}$ & $\begin{array}{c}0.2339 * * * \\
(0.000)\end{array}$ & $\begin{array}{l}0.2445^{* * *} \\
(0.000)\end{array}$ & $\begin{array}{l}0.2357 * * * \\
(0.000)\end{array}$ & $\begin{array}{l}0.2269 * * * \\
(0.000)\end{array}$ & & & \\
\hline 7. R\&D Expenditure & $\begin{array}{l}0.0093 \\
(0.873)\end{array}$ & $\begin{array}{l}-0.0413 \\
(0.479)\end{array}$ & $\begin{array}{l}-0.0456 \\
(0.434)\end{array}$ & $\begin{array}{l}-0.0411 \\
(0.481)\end{array}$ & $\begin{array}{l}-0.0411 \\
(0.481)\end{array}$ & $\begin{array}{l}0.0383 \\
(0.512)\end{array}$ & & \\
\hline $\begin{array}{l}\text { 8. Human Capital } \\
\text { (NVQ Level 4+ } \\
\text { Qualifications) }\end{array}$ & $\begin{array}{c}0.1223 * * \\
(0.035)\end{array}$ & $\begin{array}{l}0.0609 \\
(0.296)\end{array}$ & $\begin{array}{l}0.0633 \\
(0.278)\end{array}$ & $\begin{array}{l}0.0613 \\
(0.293)\end{array}$ & $\begin{array}{l}0.0595 \\
(0.308)\end{array}$ & $\begin{array}{l}0.0647 \\
(0.267)\end{array}$ & $\begin{array}{c}-0.0091 \\
(0.877)\end{array}$ & \\
\hline $\begin{array}{l}\text { 9. Labour (Working } \\
\text { Age Population) }\end{array}$ & $\begin{array}{l}0.3293^{* * *} \\
(0.000)\end{array}$ & $\begin{array}{l}0.1997 * * * \\
(0.001)\end{array}$ & $\begin{array}{c}0.198 * * * \\
(0.001)\end{array}$ & $\begin{array}{l}0.1991 * * * \\
(0.001)\end{array}$ & $\begin{array}{l}0.2025^{* * *} \\
(0.001)\end{array}$ & $\begin{array}{l}0.0154 \\
(0.792)\end{array}$ & $\begin{array}{c}0.095 \\
(0.103)\end{array}$ & $\begin{array}{c}0.158^{* * *} \\
(0.006)\end{array}$ \\
\hline
\end{tabular}

Notes: p-values in parentheses. ${ }^{*},{ }^{* *}$ and ${ }^{* * *}$ denote significance at the 10,5 and $1 \%$ level, respectively. 
Table 2: Panel Regressions of Regional Output Growth

\begin{tabular}{|c|c|c|c|c|}
\hline Gross Value Added & Model 1 & Model 2 & Model 3 & Model 4 \\
\hline Total Network Capital & $\begin{array}{c}0.0644^{* *} \\
(0.037)\end{array}$ & & & \\
\hline $\begin{array}{l}\text { Inter-Regional International } \\
\text { Network Capital }\end{array}$ & & $\begin{array}{c}0.0595 * \\
(0.053)\end{array}$ & & \\
\hline $\begin{array}{l}\text { Inter-Regional National } \\
\text { Network Capital }\end{array}$ & & & $\begin{array}{c}0.0641^{* *} \\
(0.038)\end{array}$ & \\
\hline $\begin{array}{l}\text { Intra-Regional Network } \\
\text { Capital }\end{array}$ & & & & $\begin{array}{c}0.0651^{* *} \\
(0.035)\end{array}$ \\
\hline Physical Capital & $\begin{array}{c}0.0262 * * * \\
(0.006)\end{array}$ & $\begin{array}{c}0.0262 * * * \\
(0.006)\end{array}$ & $\begin{array}{c}0.0262 * * * \\
(0.006)\end{array}$ & $\begin{array}{c}0.0263 * * * \\
(0.006)\end{array}$ \\
\hline R\&D Expenditure & $\begin{array}{l}0.0003 \\
(0.966)\end{array}$ & $\begin{array}{l}0.0003 \\
(0.965)\end{array}$ & $\begin{array}{l}0.0003 \\
(0.966)\end{array}$ & $\begin{array}{l}0.0003 \\
(0.965)\end{array}$ \\
\hline Human Capital & $\begin{array}{l}0.0406 \\
(0.187)\end{array}$ & $\begin{array}{l}0.0406 \\
(0.188)\end{array}$ & $\begin{array}{l}0.0406 \\
(0.188)\end{array}$ & $\begin{array}{l}0.0407 \\
(0.186)\end{array}$ \\
\hline Labour & $\begin{array}{c}0.8186 * * * \\
\quad(0.001)\end{array}$ & $\begin{array}{c}0.8243 * * * \\
\quad(0.001)\end{array}$ & $\begin{array}{c}0.8192 * * * \\
(0.001)\end{array}$ & $\begin{array}{c}0.8162 * * * \\
(0.001)\end{array}$ \\
\hline Spatial Lag & $\begin{array}{c}0.5779 * * * \\
(0.000)\end{array}$ & $\begin{array}{c}0.5795 * * * \\
\quad(0.000)\end{array}$ & $\begin{array}{c}0.5781 * * * \\
(0.000)\end{array}$ & $\begin{array}{c}0.5777 * * * \\
(0.000)\end{array}$ \\
\hline Constant & $\begin{array}{c}0.0069 * * * \\
(0.007)\end{array}$ & $\begin{array}{c}0.0069 * * * \\
\quad(0.007)\end{array}$ & $\begin{array}{c}0.0069 * * * \\
(0.007)\end{array}$ & $\begin{array}{c}0.0069 * * * \\
(0.007)\end{array}$ \\
\hline$N$ & 296 & 296 & 296 & 296 \\
\hline$R^{2}$ & 0.4254 & 0.4242 & 0.4253 & 0.4256 \\
\hline F-test & $\begin{array}{c}213.9 \\
(0.000)\end{array}$ & $\begin{array}{c}212.9 \\
(0.000)\end{array}$ & $\begin{array}{c}213.9 \\
(0.000)\end{array}$ & $\begin{array}{c}214.1 \\
(0.000)\end{array}$ \\
\hline Hausman Test & $\begin{array}{c}12.10 \\
(0.060)\end{array}$ & $\begin{array}{c}11.91 \\
(0.064)\end{array}$ & $\begin{array}{c}12.09 \\
(0.060)\end{array}$ & $\begin{array}{c}12.09 \\
(0.060)\end{array}$ \\
\hline
\end{tabular}

Notes: p-values in parentheses. ${ }^{*}, * *$ and $* * *$ denote significance at the 10,5 and $1 \%$ level, respectively. 